\title{
Effects of Feral Horses on Vegetation of Sable Island, Nova Scotia
}

\author{
Bill Freedman ${ }^{1,2}$, Paul M. Catling ${ }^{3}$, and Zoe LuCas ${ }^{4}$
}

${ }^{1}$ Department of Biology, Dalhousie University, Halifax, Nova Scotia B3H 4J1 Canada

${ }^{2}$ Corresponding author (email: bill.freedman@dal.ca)

${ }^{3}$ Biosystematics Research Institute, Central Experimental Farm, Agriculture Canada, Ottawa, Ontario K1A 0C6 Canada; email: catlingp@agr.gc.ca

${ }^{4}$ Sable Island Green Horse Society, P.O. Box 64, Halifax CRO, Halifax, Nova Scotia B3J 2L4 Canada; email: zoelucas@ greenhorsesociety.com

Freedman, Bill, Paul M. Catling, and Zoe Lucas. 2011. Effects of feral horses on vegetation of Sable Island, Nova Scotia. Canadian Field-Naturalist 125(3): 200-212.

To provide necessary information for the management of biodiversity on Sable Island, Nova Scotia, we studied the effects of feral horses on vegetation using exclosures and ancillary observations. Nine plant communities inside and outside of six exclosures were compared using various vegetation parameters and Mann-Whitney tests to evaluate the significance of differences. The most important findings were as follows: (1) effects of horses were greatest in the Marram (Ammophila breviligulata) grassland and much less in the communities that were not dominated by Marram Grass; (2) effects on Marram grassland varied substantially among sites; (3) the cover of standing litter of herbaceous plants was on average of 9.3 times greater inside exclosures in grassland habitats; (4) the cover of living foliage was usually higher inside exclosures, but not all differences were significant; (5) species richness and species diversity were not substantially affected; (6) the average cover of Marram Grass, the most abundant plant and a key sand binder on the island, was greater inside exclosures in six of seven study sites, significantly so in three of them; and (7) there were inconsistent differences in cover of other species at different sites. Wetland habitats cover a relatively small portion of Sable Island, but they support much of the plant biodiversity. There is evidence of strong but variable effects of horses on wetland vegetation. "Horse lawns" are littoral habitats dominated by Agrostis stolonifera (Carpet Bentgrass) and other low-growing plants. The lawn habitats represent less than $1 \%$ of the island's vegetation, and their presence is believed to be due to grazing and trampling by horses.

Key Words: Sable Island, feral (wild) horses, Equus caballus, vegetation, Ammophila breviligulata, Marram Grass, grazing, exclosures, standing litter, erosion, trampling, environmental impact, Nova Scotia.

Sable Island is located in the open Atlantic Ocean about $150 \mathrm{~km}$ east of the land mass of Nova Scotia, Canada. The island is an important location for the conservation of Canadian biodiversity. It supports several endemic taxa, including the princeps subspecies of the Savannah Sparrow (the Ipswich Sparrow) (Passerculus sandwichensis princeps Maynard) and several plants and invertebrates (Howden et al. 1970; Catling et al. 1984; Wright 1989). There are additional species of plants and animals on the island that are otherwise rare in Nova Scotia and/or Canada, as well as regionally important breeding populations of the Gray Seal (Halichoerus grypus (Fabricius)), the Harbor Seal (Phoca vitulina Linnaeus), and seabirds. Particularly well known is a population of wild horses (Equus caballus Linnaeus). Although it was established from feral animals, this herd is genetically distinct from 15 other horse breeds in eastern Canada and 5 Spanish ones, and it is therefore of conservation interest (Plante et al. 2007).

In view of these biodiversity values, substantial losses of vegetated terrain and freshwater ponds caused by erosion are serious threats to the conservation of the natural heritage of Sable Island. This concern has been heightened as a result of predictions of rising sea levels and an increasing frequency of severe storms in the North Atlantic. These could potentially reduce the veg- etated area of the island. Moreover, in October 2011, it was announced that Sable Island would be protected as a national park reserve. Conservation of its natural and cultural heritage will be key aspects of its management plan.

A number of non-native mammals as well as many alien plants have been introduced onto Sable Island (Catling et al. 1984; Wright 1989). Cattle (Bos taurus Linnaeus) were introduced around 1550 as food for shipwrecked mariners. In the mid-17th century there may have been as many as 800 free-ranging cattle, but they were eliminated by a commercial harvest and have not been present for at least two centuries (Nova Scotia Museum of Natural History 2001*). Horses were introduced onto the island in the mid-18th century and pigs (Sus scrofa Linnaeus) and sheep (Ovis aries Linnaeus) were released in 1801, but these latter species did not become established or were soon eliminated by hunting. Today, feral horses are the only terrestrial mammals on Sable Island (Welsh 1975*; Christie 1995). These animals are descended from the mid-18th century introduction, supplemented by sporadic releases of a few additional animals in the 1800s and early 1900s with the intent of "improving" the breeding stock.

Trampling and feeding activities of introduced large mammals have influenced the vegetation of Sable Island, and feral horses continue to exert an effect. In 
addition, native vegetation was disturbed during a period of subsistence and market gardening and other activities by the personnel of several life-saving stations (Catling et al. 1984). More recently, only small numbers of people have been resident on Sable Island (typically fewer than 10), limited to personnel engaged in atmospheric and ecological research and monitoring, in addition to maintaining an emergency-response capability.

During several decades prior to 1961, some horses were removed from the island for use on the mainland as working or riding animals. The intensity of this exploitation depended on the interest of the island superintendent of the time; under some superintendents, there was extensive live-harvesting on an annual basis, while others allowed only minor interventions. Since 1961, however, the horses have been protected from harassment or culling under provisions in the Sable Island Regulations made under the Canada Shipping Act (currently, the Canada Shipping Act, 2001). Their legal protection arose as a result of a controversial plan in 1960 to remove all horses from Sable Island because of damage they were presumed to be causing to its habitats as well as popular conceptions about harsh living conditions for the animals. Some people still advocate for a cull of these animals, based on concerns that this alien population might be damaging habitat, or due to unease about suffering the animals are believed to experience from injuries, illness, or other aspects of their wild circumstances. Recently, the horse population of Sable Island has ranged in late-summer abundance from about 250 to 450 animals (including foals) (estimates based on annual direct counts) (Z. Lucas, unpublished data).

Despite the ongoing controversy, there has been only one published study that focused on the effects of feral horses on habitats of Sable Island (Welsh 1975*). That work was based on observational studies of horse feeding and of seasonal forage biomass. Welsh $\left(1975^{*}\right)$ concluded that the most important effects were caused by localized trampling and destabilization of vegetation rather than by overgrazing of forage.

In North America, grazing by wild horses has been shown to reduce the richness of plant species in some situations (Beever and Brussard 2000; Beever et al. 2008) but not in others (Detling 1998), with the differences likely due to both ecosystem vulnerability and varying intensities of grazing pressure. Assateague Island on the Atlantic coast of Maryland has dune habitats comparable to those of Sable Island, and there are contrasting reports of the effects of feral horses there. Eline and Keiper (1979) reported little effect on dune vegetation, whereas De Stoppelaire et al. $(2002 *)$ suggested that "unless the size of the feral horse population is reduced, grazing will continue to foster unnaturally high rates of dune erosion."

In the present study we compare the abundance and community structure of vegetation inside and outside fenced areas established to exclude horses from the vicinity of buildings and equipment. The exclosures enabled us to examine the influences of horses, mainly grazing and trampling, on dominant plant species of the major terrestrial community types of Sable Island. This work is supplemented by additional observations of habitat changes associated with horse activity outside the exclosures. The objective is to provide information required for the management of biodiversity on Sable Island.

\section{Study Area}

Sable Island is essentially a crescent-shaped, emergent sandbar in the open ocean, with its long axis oriented east to west. It is about $47 \mathrm{~km}$ in length and has an area of $32.3 \mathrm{~km}^{2}$, of which $15.5 \mathrm{~km}^{2}$ is vegetated (Catling et al. 1984; Freedman 2001*). The mean annual temperature of Sable Island is $7.6^{\circ} \mathrm{C}$ (SD 1.5), and the annual precipitation is $146 \mathrm{~cm}(92 \%$ wet, $8 \%$ snow) (Environment Canada 2011*). All terrain on the island is susceptible to the erosion and deposition of sand, with non-vegetated habitat being especially vulnerable to these processes and mature shrub-heath habitat the least susceptible. The dynamics of sand erosion and deposition are related to the relative exposure of habitats, particularly during wind- and rain-storms.

Catling et al. (1984) described the most prominent terrestrial plant communities on Sable Island as follows: grassland dominated by Marram Grass (American Beachgrass) (Ammophila breviligulata Fern.), often with abundant Beach Pea (Lathyrus japonicus Willd. var. maritimus (L.) Kartesz \& Gandhi), Seaside Goldenrod (Solidago sempervirens L.), and Common Yarrow (Achillea millefolium L. var. occidentalis DC.); mature heath dominated by Northern Bayberry (Morella (Myrica) pensylvanica (Mirbel) Kartesz), Lowbush Blueberry (Vaccinium angustifolium Ait.), Black Crowberry (Empetrum nigrum L.), Creeping Juniper (Juniperus horizontalis Moench), Common Juniper (J. communis L. var. megistocarpa Fern. \& St. John ), and Virginia Rose (Rosa virginiana P. Mill. var. virginiana); and an intermediate type, referred to as Marram-heath transitional.

\section{Methods}

\section{Exclosures}

We studied the three plant communities (Marram grassland, mature heath, and Marram-heath transitional) in a total of nine stands in six exclosures. These fenced areas have been constructed at various times to prevent horses from utilizing habitat in the proximity of buildings, wind turbines, or arrays of scientific equipment used to monitor atmospheric conditions. The locations of the exclosures are indicated with coordinates in Table 1 and are clearly defined on the landscape by the fences, buildings, or other structures indicated in their names. Of the two wind turbine sites, $\mathrm{b}$ is the more westerly. At Main Station, the grassland site was at the northwest corner of the compound, the mesic heath on the west side, and the drier heath on the south- 
TABLE 1. Nine sampling sites with horse exclosures on Sable Island, showing the site acronym and name, age (number of years horses have been excluded), area, and dominant vegetation.

\begin{tabular}{lcccl}
\hline \hline Site and name & Age (years) & Area (ha) & Coordinates $\left({ }^{\circ} \mathrm{N},{ }^{\circ} \mathrm{W}\right)$ & Vegetation \\
\hline East Light BIO (EL-BIO) & $>20$ & 1.38 & $43.959733,59.833233$ & Marram grassland \\
Main Station (MS) & $>20$ & 5.80 & $43.930966,60.008766$ & \\
Grassland (MSgr) & $>20$ & na & $43.933900,60.006905$ & Marram grassland \\
Mesic heath (MSmh) & $>20$ & na & $43.933606,60.007543$ & Marram-heath transition \\
Drier heath (MSdh) & $>20$ & na & $43.931912,60.006120$ & mature heath \\
West Light BIO (WL-BIO) & 10 & 0.19 & $43.932066,60.023566$ & Marram grassland \\
Nova Scotia Camp (NSC) & 30 & 0.14 & $43.934183,60.047333$ & Marram grassland \\
Maritime Tel (MTT) & 20 & 0.05 & $43.931866,60.020450$ & Marram grassland \\
Wind Turbine (a) (WTa) & 4 & 0.14 & 43.92988360 .002300 & Marram-heath transition \\
Wind Turbine (b) (WTb) & 4 & 0.21 & $43.929900,60.003566$ & Marram-heath transition \\
\hline \hline
\end{tabular}

east side. The exclosures are constructed of wooden or steel posts and steel-mesh fencing. They vary in size, shape, and age (Table 1).

Horses occasionally enter some exclosures, and small numbers of Gray Seals may enter when they roam inland parts of the island during their breeding season (December through February). However, such entries are occasional (i.e., for short periods, no more than several times a year), and so are considered to be of minor importance with regard to analysis and interpretation of our field data. In addition, terns nest in or near several exclosures, in particular East Light-BIO (Bedford Institute of Oceanograpy, Department of Fisheries and Oceans), which has recently supported about 500 nests inside and fewer outside. The largest exclosure is at Main Station, with an area of 5.8 ha. It supports three major terrestrial plant communities, which were sampled separately. The other exclosures are smaller, and each supports only a single community. The exclosure at the Maritime Telegraph and Telephone Company (Maritime Tel and Tel, now Aliant) site and the exclosure at the Nova Scotia Camp have relatively small areas of vegetated habitat and much of the space is occupied by buildings, so we report summary data for the cover values for these exclosures rather than by species.

\section{Vegetation sampling at exclosures}

Vegetation was sampled in mid-August 2009, using quadrats of $1 \mathrm{~m}^{2}$ located at regular distances (usually at intervals of $10 \mathrm{~m}$, but less for the smallest exclosures) along transects that ran parallel to the exclosure fences, one quadrat on the inside and one on the outside. At each sampling point, a quadrat was sampled $3 \mathrm{~m}$ inside the fence and a paired set of quadrat was sampled $3 \mathrm{~m}$ outside. The 3-m distance was chosen to reduce effects of local trampling in the immediate external proximity of fences, which are often used as pathways and scratching places by horses and are not typical of the ambient habitat condition. For smaller exclosures, 10 quadrats were used; for larger ones, 20 quadrats were used. Within each quadrat, the percentage foliage cover was visually estimated for each species, as were the standing litter of herbaceous plants (graminoids plus forbs) and the total litter (including litter lying on the ground). The cover estimates accounted for foliage overlap, so the total cover in densely vegetated quadrats could exceed $100 \%$.

\section{Data analysis}

For each paired quadrats (inside and outside each exclosure) and for each habitat type within Main Station, the average cover and standard error were calculated for each species, the sum of all species, standing litter of herbaceous species, and total litter. Non-parametric Mann-Whitney tests were used to compare the statistical significance of differences of the most abundant species inside and outside the exclosures. Quadrats inside and outside were also compared in terms of species richness and diversity (the latter indicated by the Shannon-Wiener index, $H=-\sum p_{i} \log p_{i}$, with $p_{i}$ approximated by the relative cover of each species).

\section{Additional observations}

Observations were also made in 2008 and 2009 in relation to other habitat changes associated with feral horses.

Horse lawns: These are smaller-scale vegetational features that are commonly observed around the edge of freshwater ponds outside exclosures, a habitat where horses often spend time feeding. The vegetation is lowgrowing almost to the degree of being two-dimensional, and is dominated by grasses. A selection of three sites was sampled beside ponds at the east end of the island, each using 10 quadrats of $1 \mathrm{~m}^{2}$ each placed along a transect, supplemented by photography.

Trampling: Well-worn paths established by the observed repeated passage of horses are common in all plant communities, at scratching posts, and where animals dig to access groundwater for drinking. Vegetation of these microhabitats was documented by notes and photography.

Feeding in ponds: During the summer and autumn, horses in areas with freshwater and brackish ponds are often seen feeding on aquatic macrophytes. General observations were made of this feeding and of the apparent effects on vegetation. 
TABLE 2. Comparison of vegetation inside and outside horse exclosures. Cover data are in percentage and are the mean \pm standard error (SE), with the number of quadrats $(n)$ indicated. Species richness is the number of species present, and diversity is the Shannon-Wiener index $\left(H^{\prime}\right)$. Significant differences in cover between samples outside exclosures and samples inside exclosures are marked as follows: $*=P<0.05$, ** $=P<0.01$, and $* * *=P<0.001$.

\begin{tabular}{|c|c|c|c|c|c|c|c|}
\hline \multirow[b]{2}{*}{ Habitat } & \multirow[b]{2}{*}{ Site } & \multirow[b]{2}{*}{$(n)$} & & \multicolumn{2}{|c|}{ Cover $(\%)$} & \multirow[b]{2}{*}{$\begin{array}{c}\text { Species } \\
\text { diversity }\end{array}$} & \multirow{2}{*}{$\begin{array}{c}\text { Site-level } \\
\text { species } \\
\text { richness }\end{array}$} \\
\hline & & & & Live & $\begin{array}{c}\text { Standing } \\
\text { litter }\end{array}$ & & \\
\hline \multirow[t]{10}{*}{ Marram Grassland } & EL-BIO & 20 & Outside & $63 \pm 6$ & $7 \pm 1$ & 2.14 & 20 \\
\hline & & 20 & Inside & $115 \pm 12 * * *$ & $91 \pm 11 * * *$ & 1.66 & 19 \\
\hline & MSgr & 10 & Outside & $75 \pm 14$ & $19 \pm 5$ & 1.88 & 15 \\
\hline & & 10 & Inside & $68 \pm 13$ & $132 \pm 22 * * *$ & 1.96 & 15 \\
\hline & WL-BIO & 20 & Outside & $54 \pm 5$ & $4 \pm 1$ & 1.90 & 17 \\
\hline & & 20 & Inside & $95 \pm 21 *$ & $26 \pm 4 * * *$ & 1.56 & 17 \\
\hline & NSC & 10 & Outside & $40 \pm 8$ & $4 \pm 2$ & 2.00 & 13 \\
\hline & & 10 & Inside & $79 \pm 6 * *$ & $75 \pm 7 * * *$ & 2.18 & 16 \\
\hline & MTT & 10 & Outside & $43 \pm 5$ & $14 \pm 4$ & 1.90 & 17 \\
\hline & & 10 & Inside & $62 \pm 6$ & $122 \pm 20 * *$ & 1.38 & 14 \\
\hline \multirow[t]{6}{*}{ Marram-heath } & WTa & 10 & Outside & $60 \pm 12$ & $5 \pm 1$ & 1.84 & 20 \\
\hline & & 10 & Inside & $71 \pm 9$ & $32 \pm 12 * * *$ & 2.07 & 21 \\
\hline & WTb & 10 & Outside & $87 \pm 15$ & $4 \pm 1$ & 2.15 & 25 \\
\hline & & 10 & Inside & $74 \pm 9$ & $31 \pm 10^{* *}$ & 2.05 & 21 \\
\hline & MSmh & 10 & Outside & $72 \pm 7$ & $17 \pm 2$ & 2.43 & 29 \\
\hline & & 10 & Inside & $72 \pm 5$ & $48 \pm 18 *$ & 2.52 & 23 \\
\hline \multirow[t]{2}{*}{ Mature heath } & MSdh & 20 & Outside & $77 \pm 6$ & $1 \pm 0$ & 2.08 & 27 \\
\hline & & 20 & Inside & $107 \pm 5^{*}$ & $18 \pm 5^{* *}$ & 2.13 & 27 \\
\hline
\end{tabular}

\section{Results}

\section{Effects on major plant communities}

With respect to the cover of both live foliage and litter (Table 2) and effects on individual species (Table 3), the effects of horses were greatest in the Marram grassland and much less in the communities not dominated by Marram Grass, based on 5 Marram and 4 non-Marram sites. However, effects on Marram grasslands varied substantially between sites.

\section{Effects on plant cover}

The cover of standing litter of herbaceous plants was consistently significantly higher inside than outside exclosures. This was due to the presence of a larger amount of litter of non-eaten graminoids and forbs within the fenced areas. There was also a tendency for plant communities to have a larger cover of living foliage inside the exclosures, but only some of the differences were significant (Table 2). Overall, in the Marram grassland habitats, the cover of standing litter inside the exclosures was on average 9.3 times the cover outside exclosures (Figure 1). In the Marramheath community, the cover of standing litter inside the exclosures was on average 4.6 times the cover outside exclosures, and in the mature heath the cover of standing litter inside the exclosure was on average 18 times the cover outside the exclosure (although the absolute amount was relatively small in this habitat).

\section{Effects on species richness and diversity}

Differences in both species richness and species diversity were small and inconsistent among the study sites (Table 2). For grassland sites, the species diversity averaged 1.96 outside and 1.75 inside, while richness was 16 in both. For Marram-heath transition sites, species diversity averaged 2.14 outside and 2.21 inside, while richness was 25 and 22, respectively. For the one site of mature heath, species diversity and richness were similar inside and outside the exclosure (Table 2).

\section{Effects on particular species}

The average cover data for 47 vascular species inside and outside exclosures are indicated in Appendix 1. While these data provide a useful perspective, more important are the significance results for differences within a species (Table 3). Of 57 instances where there were sufficient data for a statistical test, 10 were significant.

Ammophila breviligulata is the most abundant plant on Sable Island, the principal sand-binding agent, and the key forage species for horses in terms of biomass consumed and time spent feeding (Welsh 1975*). The average cover of Marram Grass was less outside the three Marram grassland exclosures, significantly so in two of them (Table 3). The average cover of Marram Grass was less outside two of the three Marram-heaths sampled, but the differences were not significant. Marram Grass had significantly less cover outside the single heath exclosure than inside.

The only other instances of major vegetation dominance (Appendix 1) being substantially affected were as follows: there was significantly less cover of Poa pratensis L. (Kentucky Bluegrass) and Solidago sempervirens $\mathrm{L}$. on the outside of one grassland exclosure than on the inside, and there was significantly more cover of Juncus balticus Willd. var. littoralis Engelm. 
TABLE 3. Significance values from Mann-Whitney (Wilcoxon) tests comparing cover of vascular plant species inside and outside exclosures at nine sites. A dash (-) means that there was no occurrence or the frequency was less than $50 \%$ for sites with 20 quadrats or at least $25 \%$ for sites with 40 quadrats. Significant differences $(P<0.05)$ are indicated in bold. Within significant differences, the underlining indicates more cover inside than outside exclosures; no underlining indicates more cover outside than inside exclosures.

\begin{tabular}{|c|c|c|c|c|c|c|c|}
\hline \multirow[b]{2}{*}{ Species } & \multicolumn{3}{|c|}{ Marram grasslands } & \multicolumn{3}{|c|}{ Marram-heath transition } & \multirow{2}{*}{$\begin{array}{l}\text { Mature } \\
\text { heath } \\
\text { MSdh }\end{array}$} \\
\hline & EL-BIO & MSGr & WL-BIO & WTa & WTb & $\mathrm{MSmh}$ & \\
\hline Achillea millefolium & $\underline{0.0000}$ & 0.593 & 0.3468 & - & - & - & - \\
\hline Agrostis stolonifera & - & - & - & - & - & - & - \\
\hline Ammophila breviligulata & $\underline{0.0019}$ & 0.2676 & $\underline{0.0000}$ & 0.3532 & 0.3586 & 0.9086 & $\underline{0.0192}$ \\
\hline Anaphalis margaritacea & - & - & - & 0.8081 & 0.5409 & - & $\overline{0.0026}$ \\
\hline Anthoxanthum odoratum & - & - & - & - & - & - & - \\
\hline Arenaria lateriflora & $\underline{0.0005}$ & - & - & - & - & - & $\underline{0.0056}$ \\
\hline Aronia prunifolia & - & - & - & - & - & 0.3375 & - \\
\hline Symphytotrichum novi-belgii & - & - & 0.1656 & - & - & 0.0908 & 0.1501 \\
\hline Carex silicea & - & - & - & - & - & - & - \\
\hline $\begin{array}{l}\text { Cerastium fontanum var. } \\
\text { vulgatum }\end{array}$ & 0.4375 & - & - & - & - & - & - \\
\hline Cladina rangiferina & - & - & - & - & - & - & - \\
\hline Calystegia sepium & - & - & - & - & - & - & - \\
\hline Danthonia spicata & - & - & - & - & - & - & - \\
\hline Deschampsia flexuosa & - & - & - & - & - & - & - \\
\hline Empetrum nigrum & - & - & - & - & - & 0.5616 & 0.2368 \\
\hline Festuca rubra & 0.0744 & - & 0.6341 & 0.6155 & 0.5627 & 0.6369 & 0.8935 \\
\hline Fragaria virginiana & 0.0032 & - & - & 0.7006 & 0.0783 & 0.8182 & 0.0656 \\
\hline Hieracium scabrum. & - & - & - & - & - & - & - \\
\hline Ilex verticillata & - & - & - & - & - & - & - \\
\hline Juncus balticus & - & - & 0.0000 & - & - & - & - \\
\hline Juniperus communis & - & - & - & - & - & - & - \\
\hline Juniperus horizontalis & - & - & - & - & 0.5674 & - & 0.8048 \\
\hline Lathyrus japonicus & - & 0.2102 & - & - & - & - & - \\
\hline Leontodon autumnalis & - & - & - & - & - & - & - \\
\hline Linaria vulgaris & - & - & - & - & - & & - \\
\hline Linnaea borealis & - & - & - & - & - & - & - \\
\hline Luzula multiflora & - & - & - & - & - & - & - \\
\hline Maianthemum stellatum & - & - & - & - & - & 0.1463 & 0.8657 \\
\hline Mitchella repens & - & - & - & - & - & - & - \\
\hline Morella pensylvanica & - & - & - & 0.6756 & 0.2093 & 0.7019 & 0.3274 \\
\hline Oenothera parviflora & - & - & - & - & - & - & - \\
\hline Роа аппиа & - & - & - & - & - & - & - \\
\hline Poa pratensis & - & - & $\underline{0.0006}$ & - & - & - & - \\
\hline Plantago lanceolata & - & - & - & - & - & - & - \\
\hline Rhinanthus crista-galli & 0.1474 & - & - & - & - & - & - \\
\hline Rosa virginiana & 0.0637 & - & 0.3279 & - & 0.7578 & 0.0838 & 0.0191 \\
\hline Rubus arcuans & - & - & - & - & - & - & - \\
\hline Rumex acetosella & 0.0478 & - & - & 0.9672 & - & - & - \\
\hline Solidago rugosa & - & - & - & - & - & - & - \\
\hline Solidago sempervirens & $\underline{0.0109}$ & - & 0.3975 & 0.1925 & - & - & - \\
\hline Spartina pectinata & - & - & - & - & - & & - \\
\hline Stellaria graminea & - & - & - & & - & - & - \\
\hline Thalictrum pubescens & - & - & - & - & - & - & - \\
\hline Trientalis borealis & - & - & - & - & - & - & 0.0604 \\
\hline Trifolium repens & - & - & - & - & - & - & - \\
\hline Vaccinium angustifolium & - & - & - & - & - & - & 0.4722 \\
\hline Vaccinium macrocarpon & - & - & - & - & - & - & - \\
\hline Viburnum nudum & - & - & - & - & - & - & - \\
\hline
\end{tabular}

EL-BIO = East Light BIO; MSgr = Main Station grassland; WL-BIO = West Light BIO; WTa = Wind Turbine $(\mathrm{a})$; WTb = Wind Turbine (b); MSmh = Main Station mesic heath; MSdh = Main Station drier heath. See Table 1 for description of sites. 


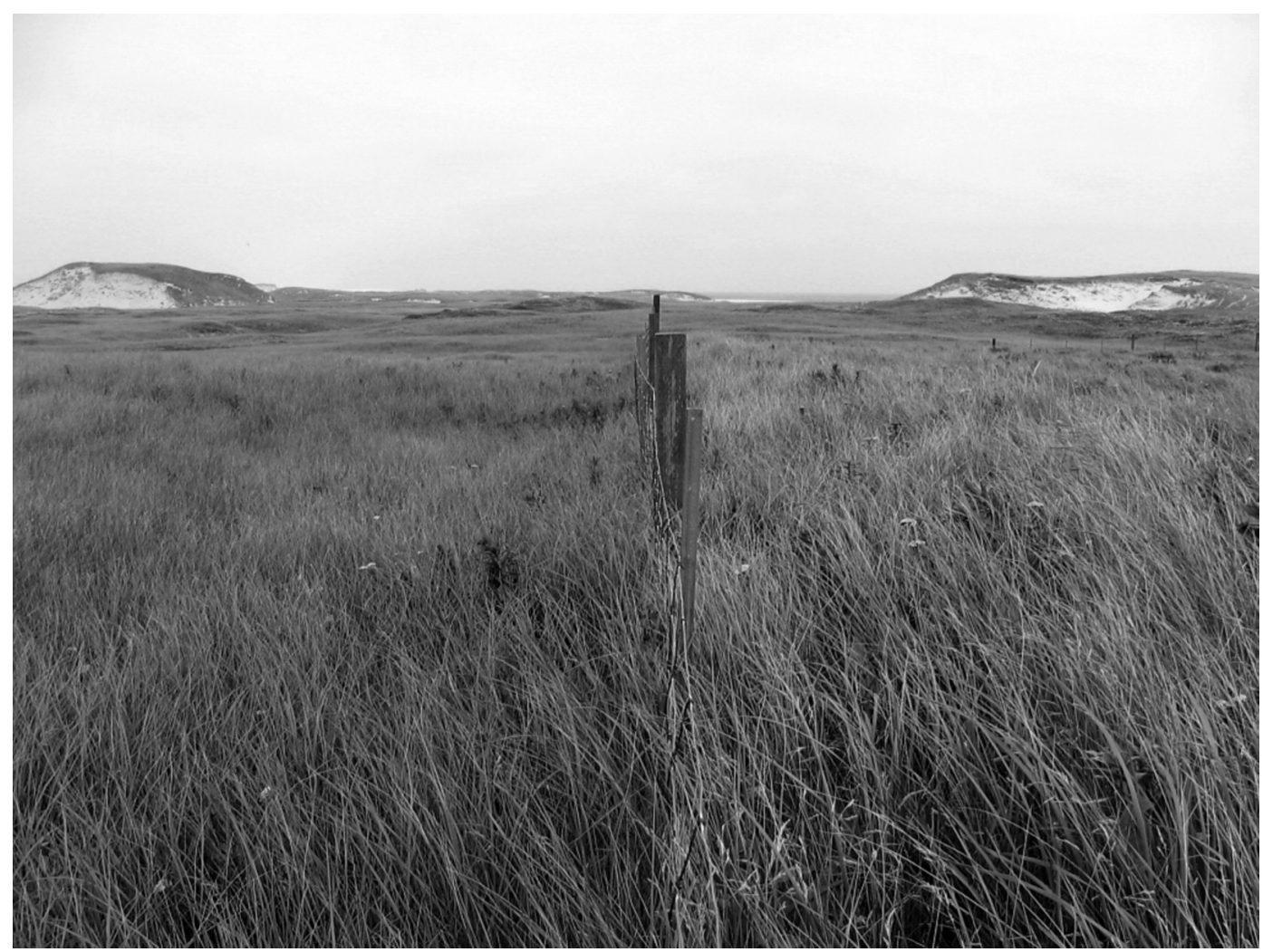

FIGURE 1. Marram-dominated grassland outside a horse exclosure at East Light BIO (to the left of the exclosure fence) and inside (to the right of the exclosure fence). The key difference is in the amount of standing dead biomass of Marram Grass and other forbs inside the exclosure. Photo: Freedman, July, 2009.

(Baltic Rush) on the outside of another grassland exclosure than on the inside. The dominant species of heathlands were not affected significantly at the single heathland exclosure.

Among the less dominant species, there was significantly more cover of Moehringia (Arenaria) lateriflora (L.) Fenzl. (Blunt-leaf Grove-sandwort) inside two exclosures than outside. Several other instances of significant effect were as follows: there was significantly more cover of Rosa virginiana and the annual alien Rumex acetosella L. (Common Sheep Sorrel) on the outside of exclosures than on the inside (Table 3), and at some sites there was significantly more cover of Anaphalis margaritacea (L.) Benth. (Common Pearlyeverlasting) and Fragaria virginiana Duchesne (Virginia Strawberry) - both of which provide abundant nectar and pollen for insect pollinators on the island -outside exclosures. Both Anaphalis margaritacea and Fragaria virginiana may be promoted by horse activity.

\section{Additional observations}

Horse lawns: The sandy shoreline of ponds on Sable Island is mostly gently sloping, and during the grow- ing season this littoral habitat progressively drains to a mesic-hydric condition. The pond-edge habitats often have a lawn-like community that is apparently produced by horses as a result of frequent close cropping and trampling (Figure 2). These "horse lawns" are dominated by alien species, particularly Agrostis stolonifera L. (Carpet Bentgrass) (Table 4). The horse lawns have a low, almost two-dimensional structure, in that they are dominated by prostrate graminoids and forbs no more than a few centimetres tall, and they are maintained in that condition by frequent grazing. Some members of this community are capable of growing much taller but are maintained in a prostrate condition by close cropping, and they may even flower and set seed in that low growth form. The horse lawns support relatively high species richness but low heterogeneity due to the single dominant. Although the horse-lawn habitats cover a small part of Sable Island (less than $1 \%$ of its area), they are disproportionately well used by horses. In places less intensively affected by horses, pond margins support nutrient-poor communities dominated by a sparse cover of graminoids, hydric and mesic forbs, and Vaccinium macrocarpon Aiton. (Cranberry). 
Trampling by horses: Horses wander extensively over Sable Island and utilize all of its terrestrial area, although they spend disproportionately more time in habitats with abundant forage, such as Marram grassland. The horses tend to utilize an extensive network of paths, which are well trampled and support greatly diminished or no vegetation over a width of typically 20-50 cm (Figure 3). There are also sparsely vegetated areas of trampled habitat, typically of $1-10 \mathrm{~m}^{2}$, in the immediate vicinity of erect features that horses use for scratching, including posts, fences, and the blownout edges of vegetated dunes. In addition, there are no ponds over about half of the length of the island, particularly in the eastern end. In those areas, horses dig in low places to expose fresh groundwater for drinking, and those waterholes have numerous radial trails leading to them. Overall, the horse trails cover an estimated $1-2 \%$ of the vegetated area of Sable Island. A minor amount of wind erosion is associated with the many horse trails, and increased sand deposition may be apparent in adjacent areas.

Feeding in ponds: Horses feed in all of the approximately 35 freshwater ponds during the summer, when the biomass of aquatic macrophytes is relatively large (Figure 4). They eat a variety of aquatic and wetland plants. Species of pondweeds, especially Stuckenia (Potamogeton) pectinata (L.) Boerner (Broadleaf Pondweed) and Potamogeton pusillus L. ssp. tenuissimus (Mert. \& Koch) Haynes and C.B. Hellquist (Small Pondweed), appeared to be eaten more frequently than other macrophytes during our late-summer surveys in 2008 and 2009. Also eaten were (alphabetically by genus): Lysimachia terrestris (L.) Britton, Sterns \& Poggemb. (Bog Loosestrife), Nuphar lutea (L.) Sm. ssp. variegata (Dur.) E. O. Beal (Variegated Yellow Pond-lily), Polygonum hydropiperoides Michx. (Swamp Smartweed), Potamogeton perfoliatus L. (Claspingleaf Pondweed), and Schoenoplectus (Scirpus) americanus (Pers.) Volk. ex Schinz \& R. Keller (American Bulrush). As well as loss of vegetation cover and likely a selective removal of certain species, aquatic habitats that are used by horses for feeding may experience considerable disturbance caused by trampling and defecation. Ponds less visited by horses appear to have more of the rarer wetland species of the island.

Manure and urine: Horse manure is widespread on Sable Island, being present even in non-vegetated sandy plains, although it is most abundant in habitats that are well used for grazing, such as Marram grassland. The manure occurs mostly as sporadic defecations by animals as they move about, as well as larger mounds known as "stud piles" that are created by stallions in their social interactions, such as to demarcate territory and defend a herd of mares (Welsh 1975*; Beever 2003).

Although the widespread occurrence of partly digested and composted manure was not directly studied by us, it undoubtedly has an influence on nutrient cycling

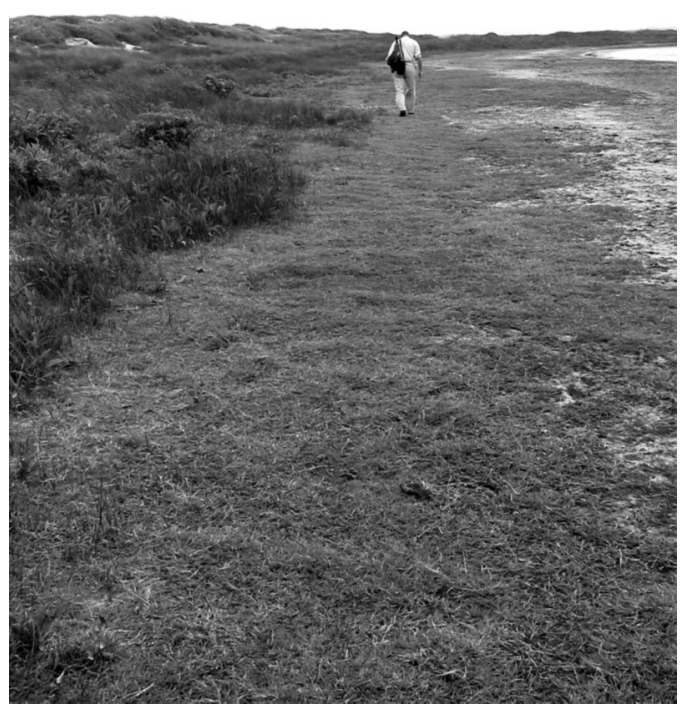

FIGURE 2. Horse lawns are decumbent, almost two-dimensional communities beside ponds that are created by closecropping and trampling by feeding horses. Photo: Freedman, July, 2009.

in terrestrial and freshwater habitats, and manure may stimulate the overall productivity of vegetation. In the absence of horses, dead forage accumulates as standing litter, which we observed inside all of the exclosure plots. Although the litter eventually decomposes, it may do so more slowly than manure. In this sense, horses may increase the rates of decomposition and nutrient cycling on Sable Island, and these processes may enhance the productivity of affected vegetation.

\section{Discussion}

The largest and most consistent effect of horse grazing that we observed on vegetation of the major terrestrial communities of Sable Island was a decrease in the biomass of standing litter in all habitats and a decrease in live Marram Grass in grassland. Various other studies of wild horses have found that, at high population levels, they may degrade their habitat by trampling and overgrazing.

Several studies have been made at Assateague Island National Seashore, a sandy barrier island in Maryland. De Stoppelaire et al. (2002*, 2004) and Seliskar (2003) examined as many as 17 exclosure plots and found that non-grazed habitat had more plant cover, taller grasses, larger biomass, and greater frequency of flowering of Ammophila breviligulata and Spartina patens (Ait.) Muhl. (Marshhay Cordgrass), the principal foods of the feral horses. Also working on exclosures on Assateague Island, Sturm $\left(2007^{*}\right)$ found that horses reduced the 
TABLE 4. Community composition of three horse lawns. Cover data are in percentage and are the mean \pm SE (10 quadrats per site).

\begin{tabular}{|c|c|c|c|}
\hline \multirow[b]{2}{*}{ Species } & \multicolumn{3}{|c|}{ Horse lawn } \\
\hline & 1 & 2 & 3 \\
\hline Achillea millefolium & 0 & $<0.1$ & 0 \\
\hline Agalinis neoscotica & $<0.1$ & 0 & 0 \\
\hline Agrostis stolonifera & $106 \pm 14$ & $67 \pm 12$ & $77 \pm 10$ \\
\hline Anthoxanthum odoratum & 0 & $<0.1$ & 0 \\
\hline bryophytes & 0 & $2.0 \pm 1.2$ & $7.1 \pm 3.2$ \\
\hline Centunculus minimus & $3.4 \pm 1.5$ & $3.8 \pm 3.1$ & $6.3 \pm 3.3$ \\
\hline Cerastium fontanum var. vulgatum & 0 & $<0.1$ & 0 \\
\hline Eleocharis sp. & $<0.1$ & 0 & $0.1 \pm 0.1$ \\
\hline Hypericum boreale & $0.3 \pm 0.2$ & $0.1 \pm 0.1$ & $0.1 \pm 0.0$ \\
\hline Juncus articulatus & $0.4 \pm 0.2$ & 0 & 0 \\
\hline Juncus balticus & $<0.1$ & $<0.1$ & 0 \\
\hline Juncus bufonius & $0.1 \pm 0.1$ & $<0.1$ & 0 \\
\hline Juncus canadensis & $0.1 \pm 0.1$ & 0 & $<0.1$ \\
\hline Leontodon autumnalis & $<0.1$ & $0.2 \pm 0.2$ & $<0.1$ \\
\hline Lycopus uniflorus & 0 & 0 & $0.8 \pm 0.8$ \\
\hline Lysimachia terrestris & 0 & 0 & $<0.1$ \\
\hline Panicum dichotomiflorum & $0.2 \pm 0.2$ & 0 & $<0.1$ \\
\hline Plantago lanceolata & $<0.1$ & $1.1 \pm 1.0$ & 0 \\
\hline Plantago major & 0 & $0.1 \pm 0.1$ & 0 \\
\hline Poa аппиа & $3.6 \pm 2.6$ & $3.8 \pm 1.6$ & $1.6 \pm 1.0$ \\
\hline Polygonum hydropiper & $0.3 \pm 0.3$ & $<0.1$ & $<0.1$ \\
\hline Ranunculus flammula & 0 & 0 & $<0.1$ \\
\hline Ranunculus repens & $0.2 \pm 0.2$ & 0 & 0 \\
\hline Rumex acetosella & 0 & $<0.1$ & 0 \\
\hline Sagina procumbens & $<0.1$ & $1.6 \pm 1.0$ & $<0.1$ \\
\hline Schoenoplectus americanus & $0.4 \pm 0.3$ & $0.5 \pm 0.5$ & $0.1 \pm 0.1$ \\
\hline Solidago sempervirens & 0 & $<0.1$ & 0 \\
\hline Sphagnum sp. & 0 & 0 & $0.5 \pm 0.3$ \\
\hline Taraxacum officinale & 0 & $<0.1$ & 0 \\
\hline Trifolium repens & $2.3 \pm 1.6$ & $5.0 \pm 1.7$ & 0 \\
\hline Vaccinium macrocarpon & 0 & $<0.1$ & 0 \\
\hline Viola lanceolata & 0 & $<0.1$ & $0.3 \pm 0.2$ \\
\hline Total cover & $117 \pm 42$ & $86 \pm 26$ & $94 \pm 25$ \\
\hline Species richness & 18 & 22 & 17 \\
\hline Species diversity $(H)$ & 0.7 & 1.3 & 1.1 \\
\hline
\end{tabular}

abundance of forage species and the species richness, evenness, and diversity of their communities. On a barrier island at Cape Lookout National Seashore, North Carolina, Barber (2001) found that grazing by horses and cattle resulted in grasslands that are relatively shortstatured and of sparse cover compared with habitat protected by fencing. De Bonte et al. (1999) examined a coastal dune system in the Netherlands, and they found that areas newly grazed by horses and cows had a reduced abundance of palatable species and an increase in the abundance of less-palatable ones, although there was an overall increase in species richness.

Studies have also been made in inland habitats, where wild horses maintain much larger and widerranging populations than on coastal islands. Beever and Brussard (2000) used exclosures to study the effects of feral horses on montane vegetation in Nevada, and they found greater plant cover, height, and species richness where grazing had been prevented. In a largerscale study of 19 montane sites across nine mountain ranges in the Great Basin of the southwestern U.S.,
Beever et al. (2003, 2008) found greater plant cover and species richness at sites from which wild horses had been removed, especially of species that the animals prefer as forage. Studies at the Sheldon National Wildlife Refuge in Nevada found a greatly increased biomass of forage species in exclosure plots for wild horses and burros (Equus africanus asinus Linnaeus), as well as a rapid recovery of vegetation after these animals were removed from the greater habitat (U.S. Fish and Wildlife Service 2010*). Abella (2008) reviewed the effects of wild burros on vegetation in the Mohave Desert of the southwestern U.S. and found that forage grasses were 3 to 9 times more abundant inside exclosures that excluded large herbivores (of which burros were the most abundant).

Our observation of "horse lawns" is comparable to reports of lawn-like habitats elsewhere created by close cropping by feral sheep, such as the "biotic grasslands" on the island of Hirta off northwestern Scotland (Gwynne et al. 1974). We have also observed coastal lawn-like habitats created by sheep on islands off Nova 


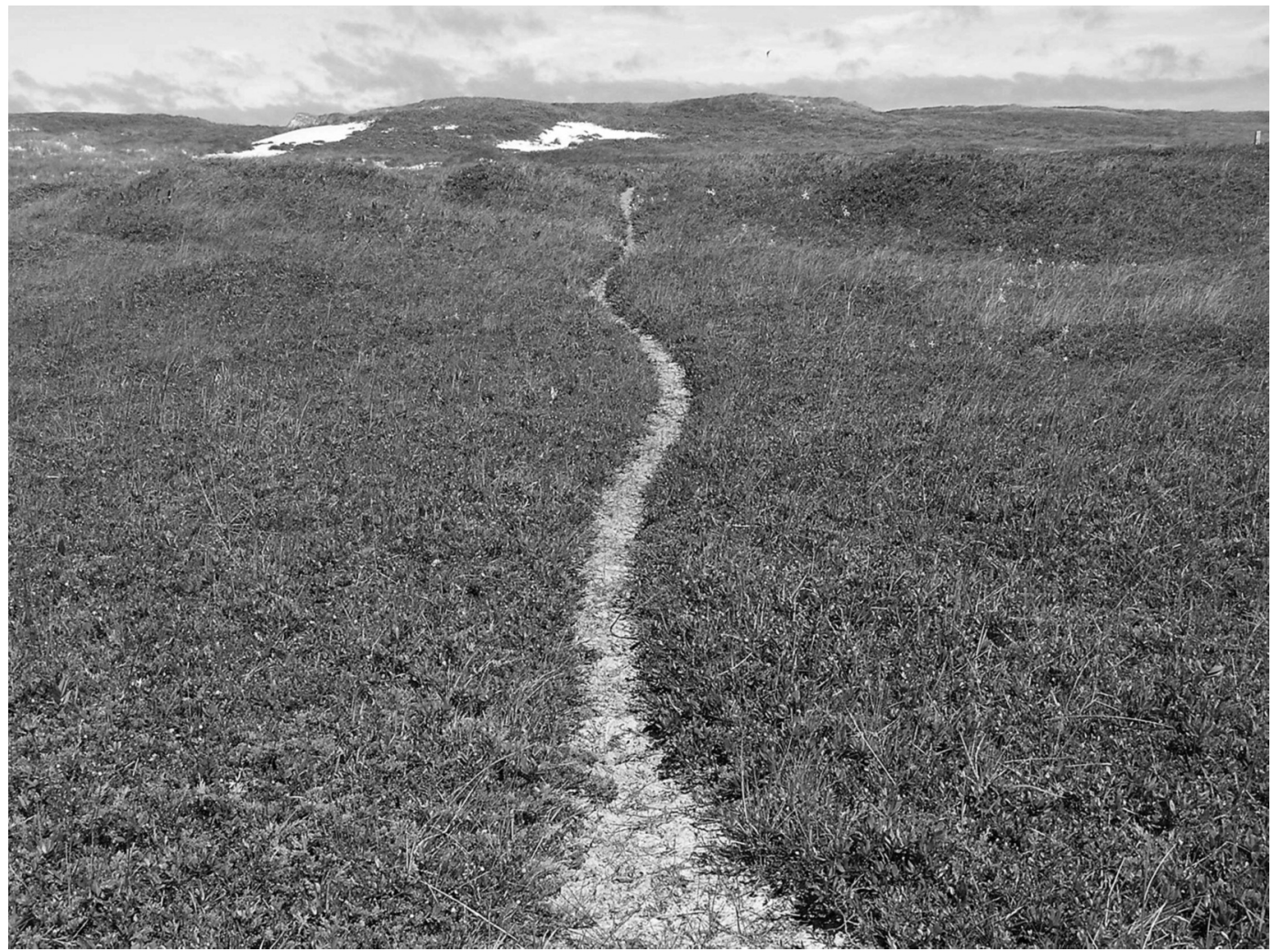

FIGURE 3. A path through mature heath created by frequent passage of horses. Photo: Freedman, July, 2009.

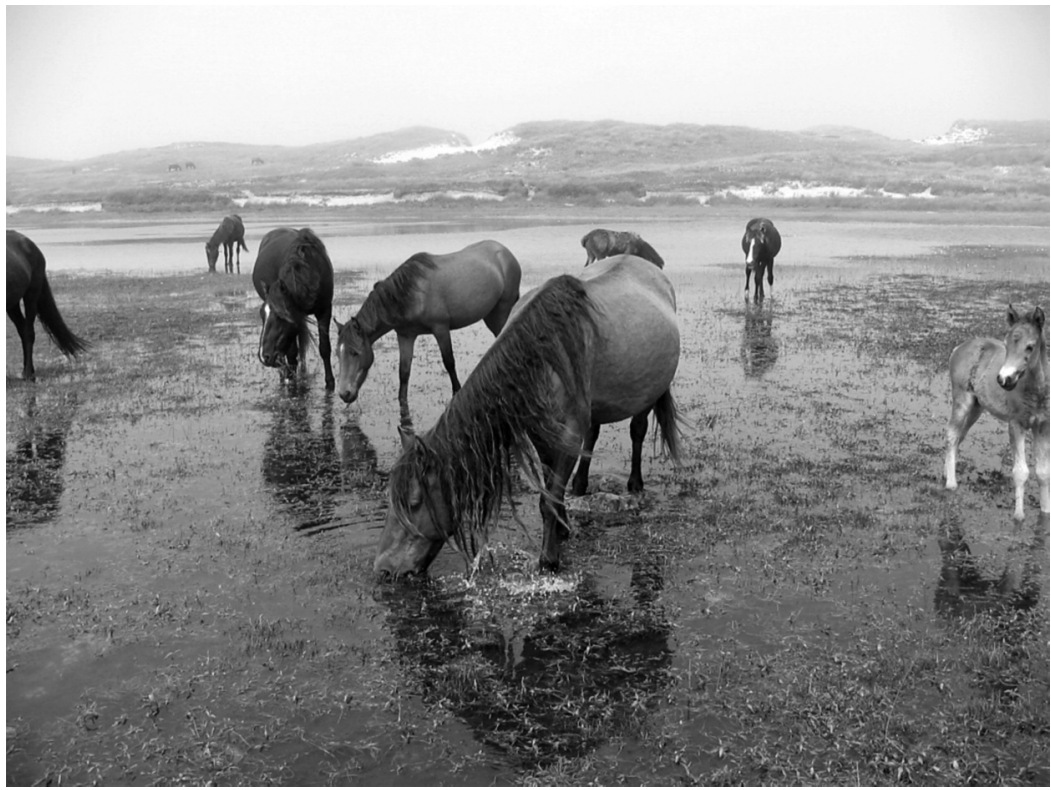

FIGURE 4. Horses feeding in a freshwater pond. Horses cause disturbance by trampling, removing forage, and defecating. Photo: Freedman, July, 2009. 
Scotia where the terrain is rocky drumlin with a natural cover mostly of conifer forest and heath, rather than sandy grasslands as on Sable Island (unpublished observations).

Our most important observations with respect to exclosures were as follows: (1) effects of horses were greatest in the Marram grassland and much less in the communities not dominated by Marram Grass; (2) effects on Marram grassland varied substantially between sites; (3) there was a larger accumulation of standing litter of herbaceous plants inside all horse exclosures; (4) a higher cover of living foliage occurred inside of most exclosures, although not all differences were significant; (5) there were no substantial effects on species richness and diversity; (6) the cover of Ammophila breviligulata, the most abundant plant and the key forage species for horses, was greater inside six of the seven exclosure habitats, significantly so in three of them, two of which were in Marram grassland; and (7) there were inconsistent differences in the cover of other species at different sites. Although wetland habitats did not occur in the exclosures, there is evidence of a strong but variable effect on these habitats caused by feeding and trampling by horses.

Because of the unique biodiversity values of Sable Island and the fact that it is to become a national park, there is a need for information to guide its stewardship. The Canada National Parks Act states that the "maintenance or restoration of ecological integrity, through the protection of natural resources and natural processes, shall be the first priority of the Minister when considering all aspects of the management of parks." The Canada National Parks Act defines ecological integrity as follows: "ecological integrity means, with respect to a park, a condition that is determined to be characteristic of its natural region and likely to persist, including abiotic components and the composition and abundance of native species and biological communities, rates of change and supporting processes."

In this context, the horses of Sable Island, being a feral population of an alien large mammal, might be viewed as posing a challenge to the ecological integrity of the island. However, managing the presence or abundance of the wild horses of Sable Island would be highly controversial. In any event, such a judgment would need to be informed by reliable information about the ecological effects of these animals.

In fact, it is likely that horses and other non-native biota have caused substantial changes to Sable Island since they were introduced several centuries ago, as have disturbances associated with other anthropogenic influences, such as the cultivation of food crops and the passage of vehicles over sensitive terrain. These various influences have undoubtedly contributed to the destabilization of dunes, leading to increased erosion and blowouts and effects on the species composition, relative abundance, and productivity of plant communities. There are no studies of the earlier changes, al- though relevant comments were made about vegetation damage by large mammals in some historical journals (Catling et al. 1984). It seems, however, that ecological changes caused by horses on Sable Island have stabilized in recent decades, during which time their abundance has ranged from about 250 to 450 animals.

To provide a more complete understanding of the effects of horses on the vegetation of Sable Island, we recommend monitoring of the existing exclosures over the long term and perhaps the installation of additional exclosures in key habitats, as well as focused studies of the effects of horses on freshwater wetlands, which support much of the rarer biodiversity of the island.

\section{Acknowledgements}

This work was supported by research grants to the Friends of the Green Horse Society provided by ExxonMobil Canada Ltd. and to B. F. from the Natural Sciences and Engineering Research Council of Canada. We thank Erik Beever for his comments on an early draft of the manuscript. Advice on statistical analyses was received from Hal Whitehead, Department of Biology, and Chris Field and David Hamilton of the Department of Mathematics and Statistics, all of Dalhousie University. We are grateful to Brenda Kostiuk and George-Anne Merrill for their assistance with fieldwork. Gerry Forbes and other staff of the Sable Island Science Station assisted with logistics and other services on Sable Island. Three anonymous referees provided helpful comments and suggestions.

\section{Documents Cited (marked $*$ in text)}

De Stoppelaire, G. H., J. Brock, C. Lea, M. Duffy, and W. Krabill. 2002. GS, NPS, and NASA investigate horsegrazing impacts on Assateague Island dunes using airborne LIDAR surveys. USGS Open File Report 01-382. Center for Coastal and Regional Marine Studies, St. Petersburg, Florida.

Environment Canada. 2011. Canadian climate normals or averages, 1971-2000. National Climate Data and Information Archive. Weather Office, Environment Canada, Ottawa, Ont. http://climate.weatheroffice.gc.ca/climate_normals/ index_e.html.

Freedman, B. 2001. Airphoto assessment of changes in vegetation cover on Sable Island, Nova Scotia. Research Report to the Canadian Wildlife Service, Atlantic Region, Sackville, N.B.

Nova Scotia Museum of Natural History. 2001. Sable Island: A story of survival. http://museum.gov.ns.ca/mnh /nature/sableisland/english_en/index_en.htm. (Accessed August 2010).

Sturm, M. 2007. Assessment of the effects of feral horses, Sitka deer and white-tailed deer on Assateague Island's forest and shrub habitats. National Park Service, Assateague Island National Seashore.

U.S. Fish and Wildlife Service. 2010. Horse and burro management. Sheldon National Wildlife Refuge, Denio, Nevada.

Welsh, D. A. 1975. Population, behavioural and grazing ecology of the horses of Sable Island. Ph.D. thesis, Dalhousie University, Halifax, N.S. 


\section{Literature Cited}

Abella, S. R. 2008. A systematic review of wild burro grazing effects on Mojave Desert vegetation, USA. Environmental Management 41: 809-819.

Barber, D. C. 2001. Influence of grazing on barrier island vegetation and geomorphology, coastal North Carolina. Annual Meeting of the Geological Society of America, Boston, Massachusetts.

Beever, E. A. 2003. Management implications of the ecology of free-roaming horses in semi-arid ecosystems of the western United States. Wildlife Society Bulletin 31: 887895.

Beever E. A., and P. F. Brussard. 2000. Examining ecological consequences of feral horse grazing using exclosures. Western North American Naturalist 60: 236-254.

Beever, E. A., R. J. Tausch, and P. F. Brussard. 2003. Characterizing grazing disturbance in semi-arid ecosystems across broad scales, using diverse indices. Ecological Applications 13: 119-136.

Beever, E. A., R. J. Tausch, and W. E. Thogmartin. 2008. Multi-scale responses of vegetation to removal of horse grazing from Great Basin (USA) mountain ranges. Plant Ecology 196: 163-184.

Catling, P. M., B. Freedman, and Z. Lucas. 1984. Vegetation and phytogeography of Sable Island, Nova Scotia. Proceedings of the Nova Scotian Institute of Science 24: 181-248.

Christie, B. 1995. The Horses of Sable Island. Second edition. Pottersfield Press, Halifax, N.S.

De Bonte, A. J., A. Boosten, H. G. J. M. van der Hagen, and K. V. Sykora. 1999. Vegetation development influenced by grazing in the coastal dunes near The Hague, the Netherlands. Journal of Coastal Conservation 5: 59-68.
De Stoppelaire, G. H., T. W. Gillespie, J. C. Brock, and G. Tobin. 2004. Use of remote sensing techniques to determine the effects of grazing on vegetation cover and dune elevation at Assateague Island National Seashore: impact on horses. Environmental Management 34: 642-649.

Detling, J. K. 1998. Mammalian herbivores: ecosystem-level effects in two grassland national parks. Wildlife Society Bulletin 26: 438-448.

Eline, J. F., and R. Keiper. 1979. Use of exclusion cages to study grazing effects on dune vegetation on Assateague Island, Maryland, USA. Proceedings of the Pennsylvania Academy of Science 53: 143-144.

Gwynne, D., C. Milner, and M. Hornung. 1974. The vegetation and soils of Hirta. Pages 36-87 in Island Survivors: The Ecology of the Soay Sheep of St. Kilda. Edited by P. A. Jewell, C. Milner, and M. Boyd. Athlone Press, London, U.K.

Howden, H. F., J. E. H. Martin, E. L. Bousfield, and D. E. McAllister. 1970. Fauna of Sable Island and its zoogeographic affinities - a compendium. National Museum of Canada Publications in Zoology 4: 1-45.

Plante, Y., J. L. Vega-plas, Z. Lucas, D. Colling, B. De March, and F. Buchanan. 2007. Genetic diversity in a feral horse population from Sable Island, Canada. Journal of Heredity 98: 594-602.

Seliskar, D. M. 2003. The response of Ammophila breviligulata and Spartina patens (Poaceae) to grazing by feral horses on a dynamic mid-Atlantic barrier island. American Journal of Botany 90: 1038-1044.

Wright, B. 1989. The fauna of Sable Island. Curatorial Report No. 68. Nova Scotia Museum, Halifax, N.S.

Received 4 January 2010

Accepted 9 March 2011 


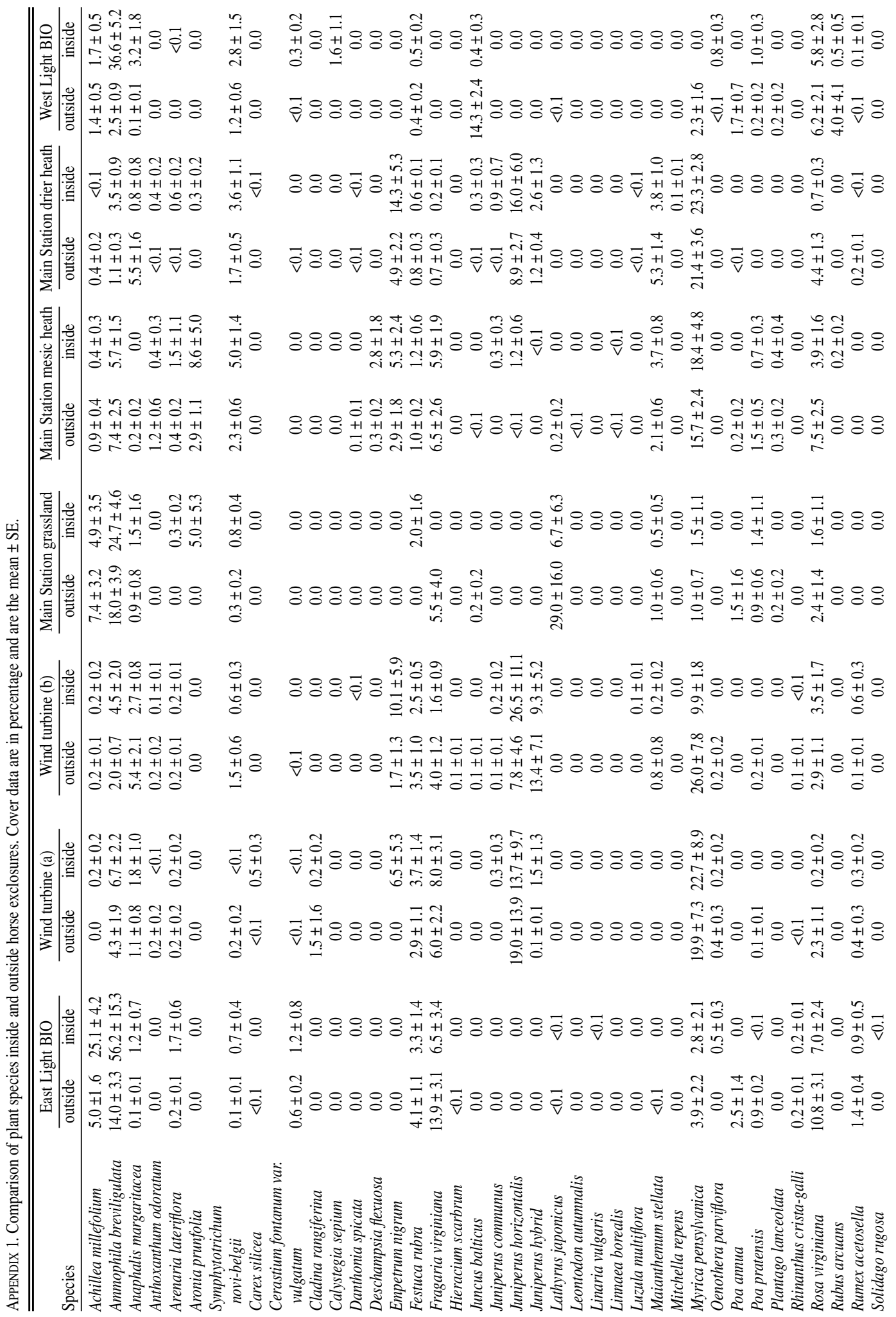




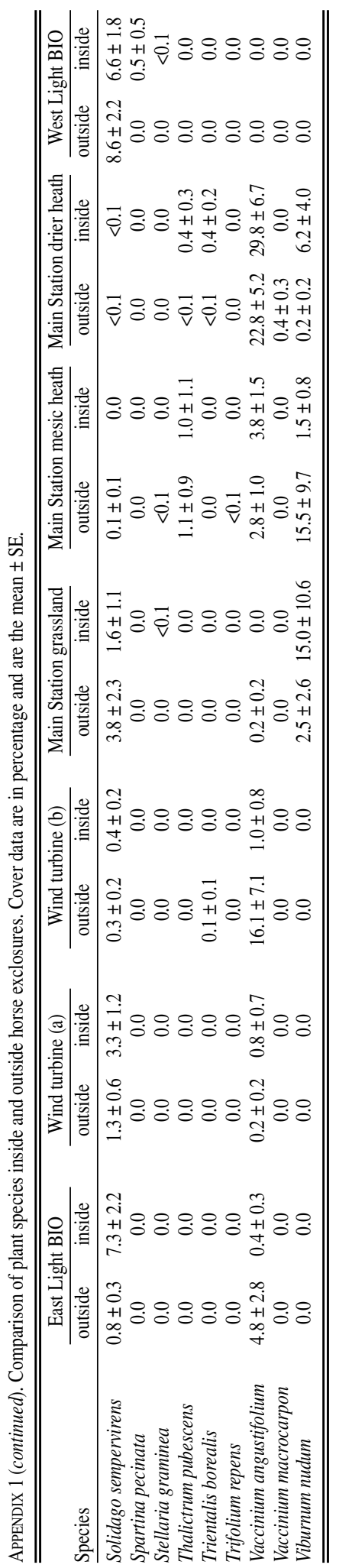

